\title{
Chinese College Students' English Grammar I Pragmatic Awareness and Competence
}

\author{
Mengqing Zhu \\ Jilin Agricultural University, Changchun, Jilin 130011, China \\ Email: zhumengqingjulia@163.com
}

Key words: grammar consciousness; pragmatic awareness; grammatical competence; pragmatic competence; English study

Abstract:This research adopts questionnaire on College English Majors' grammatical and pragmatic awareness degree was investigated, focusing on the relationship between China English Majors' grammar consciousness and grammatical competence, pragmatic awareness and pragmatic competence. The results of the study show that Chinese English Majors' pragmatic and grammatical awareness is not high enough, but the former is significantly higher than the latter. There is a significant correlation between the degree of pragmatic awareness and pragmatic competence, the level of grammatical awareness and the level of grammatical competence of Chinese English majors. In view of the importance of the level of consciousness to the development of language competence and the low level of pragmatic and grammatical awareness of Chinese English majors. In this paper, we should pay attention to the cultivation of students' pragmatic and grammatical awareness in English teaching, so as to improve their English language proficiency and pragmatic competence.

\section{Introduction}

The ultimate goal of foreign language teaching is to enable students to master the foreign language and communicate in a foreign language. Almost any syllabus, textbooks and foreign language teachers will emphasize that the ultimate goal of foreign language teaching is to cultivate students' communicative competence. According to the theoretical model of Bachman, communicative competence consists of 3 parts: linguistic competence, strategic competence and psychological mechanism. Language competence is further divided into structural organization ability and pragmatic competence ${ }^{[1-2]}$. The ability to organize structure includes grammatical competence, which refers to the ability of the speaker to produce the correct sentences according to the syntactic and semantic rules. Pragmatic competence refers to the various kinds of knowledge used by the communicators in the process of discourse according to the situation of context and the proper behavior. It can be seen that grammatical competence and pragmatic competence are an integral part of communicative competence, and the cultivation of students' communicative competence is inseparable from the cultivation of students' grammatical and pragmatic competence ${ }^{[3-4]}$. Due to the influence of structuralism and the practice of traditional Chinese idioms, College English teachers have always attached importance to the research and development of grammatical competence.

Since twenty-first Century, more and more researches have been made on the pragmatic competence of English learners. There is a great difference between Chinese and English in the pragmatic strategies. In the absence of intervention in classroom teaching, the learners can acquire pragmatic competence? This is a worthwhile and valuable question. However, the research on pragmatic competence of learners in China mainly focuses on the measurement and description of pragmatic competence, pragmatic competence and personality, learning motivation and learning strategies ${ }^{[5]}$. The research on the development of College Students' foreign language in China mainly focuses on the development of College Students' English grammar, vocabulary, syntax and so on. There are few longitudinal studies on the development of learners' pragmatic competence. Kasper believes that the development of pragmatic competence is closely related to pragmatic, grammatical competence and grammatical awareness. Therefore, it is necessary to pay attention to grammatical competence and grammatical awareness. This study will focus on English Majors' English grammar, pragmatic awareness and competence development. In this paper, based on the research results of 
English acquisition, the relationship between pragmatic awareness and pragmatic competence, grammatical awareness and grammatical competence is discussed ${ }^{[6-8]}$.

\section{Research design}

\subsection{The adopted method}

In this study, a questionnaire survey was conducted to investigate the grammatical and pragmatic awareness of College English majors. Because the sample is larger, the questionnaire survey method is adopted. The research tool of this study is "Chinese college students' English grammar and pragmatic awareness questionnaire". A total of 20 questionnaires were set up, 8 of which were used to test the grammatical errors, and the other one was the pragmatic failure of the 8 questions, and the other one was the 4 item. In the test of pragmatic failure for social pragmatic failure, that the speaker does not pay attention to the conversation of the status, the identity is low or close by the words people use the expression way too polite, or of high status or distant relationship by way of expression if people use more familiar or rude, do not use language well, not polite. The test is divided into two steps, the first step to judge, for every one right one, reflecting the grammatical and pragmatic competence. The second step, in the absence of errors ( 0 points) to the error is very serious ( 5 points) on the level of the table on the choice of the score reflects the grammatical and pragmatic awareness of the six.

\subsection{Group comparison}

The participants were 250 students of freshman, sophomore and junior of English major at a local college. One of the two parallel classes, a total of 75 people; sophomore has a total of two parallel classes, a total of 55 people; junior three parallel classes, a total of 120 people, as shown in figure 1. The English Majors in the school are relatively stable, mainly using the traditional teaching methods, no special pragmatic teaching or cross-cultural communication training. In order to ensure the effectiveness of the test, in conjunction with for teachers, teachers in class by questionnaire issued, the time limit and recovered on the spot. After the questionnaire recovery, assignment, data input SPSS15.0 software for processing. In this study, in order to facilitate the research and presentation, we regard the grade one or two students as the low level group, the grade three students as high level group.

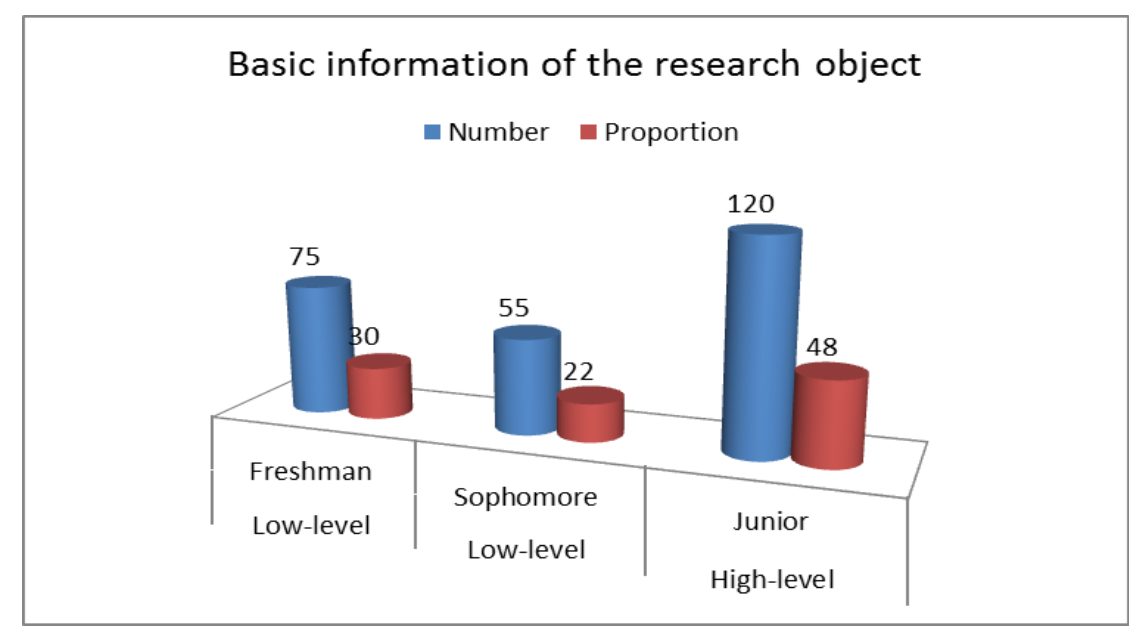

Fig.1 Basic information of the research object

\section{Results and discussion}

\subsection{Overall learning situation}

The results of the study show that college students' grammatical awareness and grammatical competence are higher than their pragmatic awareness and pragmatic competence. The difference is 
that the former study found that the difference reached a significant level, while the latter did not find significant differences. Here we look at the overall situation of college students in china.

Table.1 General Situation

\begin{tabular}{l|llll}
\hline & average value & Standard deviation & The value of T & P \\
\hline Grammar consciousness & 1.5103 & 1.075 & -10.0812 & 0 \\
Pragmatic awareness & 3.3726 & 1.0208 & & \\
\hline grammatical competence & 0.4763 & 0.2647 & -8.654 & 0 \\
Pragmatic competence & 0.8354 & 0.1683 & & \\
\hline
\end{tabular}

From table 1, it can be found that college students' pragmatic awareness is significantly higher than that of their grammatical awareness. Because in this experiment are adults, the results can be explained as to pay more attention to English teaching Chinese to cultivate students' communicative ability, China college students pay more attention to the appropriateness of the use of English in the process of foreign language. The tendency to pay attention to pragmatics is consistent with the results of the study. However, it should not be neglected that the grammar awareness and grammatical competence of the learners in this study are low. To a certain extent, it is pointed out that the popular communicative teaching method has its defects, which is the cultivation of communicative competence to some extent. It should be pointed out that the phenomenon of low grammar ability of the students can only prove that the grammar knowledge is weak.

\subsection{Comparison of different levels}

Some studies have found that foreign language learners in different language proficiency groups are not in the same level of pragmatics and grammar acquisition. As can be seen from table 2, the high level group's grammar consciousness is lower than the low level group, the difference is not significant, and the grammar ability is lower than the low level group, the difference is not significant. However, the pragmatic awareness of the high level group was higher than that of the low level group, the difference was not significant, and the pragmatic competence was higher than that of the low level group, but the difference was not significant. In a word, the grammatical awareness and grammatical competence of the high-level group were lower than those of the lower level group, while the pragmatic awareness and pragmatic competence were higher than that of the low level group, but all the differences were not significant. This shows that with the growth of English learning and the improvement of English proficiency, students pay more attention to the appropriateness of language, while the tolerance for grammatical errors is higher and higher, and the accuracy of language has declined. 
Table.2 Comparison of High and Low Level Group

\begin{tabular}{c|c|c|c|c|c|c}
\hline & \multicolumn{2}{|c|}{ High-level } & \multicolumn{2}{c|}{ Low-level } & \multicolumn{2}{c}{ Contrast } \\
\hline & $\begin{array}{c}\text { average } \\
\text { value }\end{array}$ & $\begin{array}{c}\text { standard } \\
\text { deviation }\end{array}$ & $\begin{array}{c}\text { average } \\
\text { value }\end{array}$ & $\begin{array}{c}\text { standard } \\
\text { deviation }\end{array}$ & $\begin{array}{c}\text { The value } \\
\text { of T }\end{array}$ & Saliency \\
\hline $\begin{array}{c}\text { Grammar } \\
\text { consciousnes } \\
\text { s }\end{array}$ & 1.3254 & 0.9263 & 1.6521 & 1.1736 & -1.649 & 0.089 \\
\hline $\begin{array}{c}\text { Pragmatic } \\
\text { awareness }\end{array}$ & 2.4586 & 2.3837 & 2.3845 & 1.1089 & 0.802 & 0.457 \\
\hline $\begin{array}{c}\text { Grammatical } \\
\text { competence }\end{array}$ & 0.5208 & 0.2506 & 0.5628 & 0.2694 & -0.407 & 0.642 \\
\hline $\begin{array}{c}\text { Pragmatic } \\
\text { competence }\end{array}$ & 0.8035 & 0.1894 & 0.8157 & 0.1802 & 0.128 & 0.879 \\
\hline
\end{tabular}

\section{Summary}

On the whole, Chinese EFL learners' pragmatic awareness and pragmatic competence are significantly higher than their grammatical awareness and grammatical competence. On the one hand, with the development of communicative approach, the reform of English Teaching in China has made some achievements, and the learners' pragmatic awareness and pragmatic competence have been developed. On the other hand, the results of this study, while affirming the achievements of communicative language teaching, also exposed its shortcomings, that is, ignoring the cultivation of grammatical competence. In the context of group comparison, both the high level group and the low level group were significantly higher than their level of grammatical awareness and grammatical competence. That is to say, regardless of the level of language, Chinese English Majors' pragmatic awareness is significantly higher than that of their grammatical awareness, and their pragmatic competence is significantly higher than that of their grammatical competence. The data of this study show that the pragmatic competence of Chinese college students is higher than that of their grammatical competence, and that the development of pragmatic competence is prior to the development of pragmatic competence.

\section{Acknowledgments}

This work is supported by the Science Research Foundation of Jilin Agricultural University: Chinese College Students' English Grammar / Pragmatic Awareness and Competence-Take Jilin Agricultural University as examples (No. 201648).

\section{References}

[1] Sorour, Nourhan. Grammatical versus pragmatic awareness: the case of Egyptian students in an English-medium university[J]. 2015.

[2] Rui L I, Suleiman R R R, Sazalie A. The Relationship between Motivation and Pragmatic Awareness: A Case Study of Chinese EFL Learners[J]. 3l Southeast Asian Journal of English Language Studies, 2015.

[3] Mou X M. The Relationship among English Proficiency,Learning Motivation and Grammatical and Pragmatic Awareness/Competence[J]. Journal of Heilongjiang College of Education, 2012.

[4] Xuan-Min W U. On Vocational Business English Majors' Personality Types,Grammatical/Pragmatic Competence and Awareness[J]. Journal of Huaihai Institute of Technology, 2012.

[5] Yan L X. Research on English majors' grammatical,pragmatic awareness and ability development[J]. Journal of Anhui University of Science \& Technology, 2012.

[6] Chen L J. Action Research on Cultivating Pragmatic Awareness of College Students[J]. Higher Education Forum, 2012. 
[7] Zhang X. Cultivating Students' Pragmatic Competence in Translation Teaching of English Majors[J]. Journal of Changshu Institute of Technology, 2014.

[8] Huang W, Hong-Zhang F U, University S. On Cultivating Intercultural Pragmatic Competence for College Students in English Teaching[J]. Overseas English, 2014. 